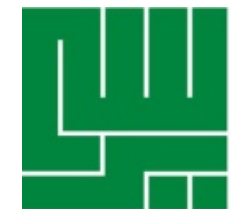

\title{
Penerapan Token Economy dan Teknik Prompting untuk Meningkatkan Keterampilan Berpakaian pada Remaja dengan Disabilitas Intelektual Taraf Sedang
}

\author{
The Application of Token Economy and \\ Prompting Techniques to Enhance Self-Dressing Skill for \\ Adolescent with Moderate Intellectual Disability
}

Amanda Anggriani Kinasih, Ike Anggraika

Fakultas Psikologi Universitas Indonesia

Email: amanda.anggriani@gmail.com

\begin{abstract}
KATA KUNCI Disabilitas Intelektual, Keterampilan Berpakaian, Modifikasi Perilaku, Token Economy, Prompting.
\end{abstract}

KEYWORDS

Intellectual Disability, Self-Dressing Skill, Behavior Modification, Token Economy, Prompting.

ABSTRAK Anak dengan disabilitas intelektual memiliki masalah dengan fungsi adaptif, salah satunya ialah kemampuan bina diri. Salah satu kemampuan bina diri yang penting untuk dikuasai oleh anak adalah berpakaian secara mandiri, terutama bila anak sudah menginjak usia remaja, agar anak tidak lagi bergantung pada orang dewasa. Tujuan penelitian ini adalah untuk meningkatkan keterampilan berpakaian pada remaja dengan disabilitas intelektual melalui program modifikasi perilaku. Keterampilan berpakaian diukur dengan durasi yang dibutuhkan anak untuk selesai mengenakan pakaian dengan tepat. Desain penelitian ini menggunakan single case experimental A-B design. Partisipan dari penelitian ini ialah seorang anak perempuan berusia 14 tahun 11 bulan dengan disabilitas intelektual level sedang (moderate). Teknik yang digunakan dalam program modifikasi perilaku ini ialah token economy serta prompting. Intervensi mencakup tiga sesi baseline, 15 sesi intervensi, serta tiga sesi follow-up. Data dianalisis menggunakan teknik analisis visual, yakni membandingkan durasi yang dibutuhkan anak untuk berpakaian secara tepat sebelum dan setelah intervensi dilakukan. Hasil penelitian ini menunjukkan bahwa terdapat penurunan durasi berpakaian yang signifikan, yakni hampir 6 kali lebih cepat yaitu dari total 65 menit (tahap baseline) hingga total 11 menit (tahap follow-up) untuk lima jenis pakaian. Hal tersebut menandakan bahwa anak lebih terampil dalam mengenakan pakaian tanpa bantuan dari orangtua. Hasil penelitian ini mengimplikasikan bahwa modifikasi perilaku 
dapat menjadi alternatif intervensi untuk meningkatkan keterampilan berpakaian pada remaja yang memiliki disabilitas intelektual sedang.

ABSTRACT Children with intellectual disability has deficit in adaptive functioning, and one of them is self-help skill. Self-dressing skill is one of the most important self-help skills that need to be mastered by children, especially when they already going to adolescent phase. Self-dressing skill need to be taught for them to be independent and require less help from their caregiver. The aim of this study is to enhance self-dressing skill on children with moderate intellectual disability through behavior modification program. A single case experimental A-B design is employed in this study, with three baseline sessions, 15 treatment sessions, and three follow-up sessions. The participant is a 14 years - 11 months old girl who diagnosed with moderate intellectual disability. Token economy and prompting techniques were used in this study. The data was analyzed using visual analysis technique, by comparing data acquired in baseline phase (pretest), posttest, and follow-up. The data measured is the duration the child needs in completing five types of clothing (bra, t-shirt, shirt, pants, and skirt). Results of this study revealed that the duration needed to self-dress was almost 6 times faster after the intervention was given, which is from a total of 65 minutes (on baseline session) to 11 minutes (on follow-up session) for completing five types of clothing. Such result indicate that the combination of token economy and prompting techniques is effective to lower the duration of selfdressing, therefore, enhance the child's self-dressing skill. To conclude, the current study implicates that behavior modification could be used as an intervention to enhance selfdressing skill in adolescence with moderate intellectual disability. 


\section{PENDAHULUAN}

Berdasarkan DSM V, intellectual disability (ID atau disabilitas intelektual) merupakan gangguan yang ditandai dengan adanya keterbatasan fungsi intelektual (dengan IQ di bawah 75) serta fungsi adaptif khususnya dalam domain konseptual, sosial, dan praktikal (APA, 2013). Adanya keterbatasan dalam fungsi adaptif pada umumnya menyebabkan anak gagal memenuhi tuntutan perkembangan dan sosiokultural dalam hal kemandirian dan tanggungjawab sosial (Mash \& Wolfe, 2010). Untuk itu, anak dengan disabilitas intelektual memerlukan pelatihan khusus agar berdaya secara mandiri ketika beranjak dewasa.

Di Indonesia sendiri, prevalensi disabilitas intelektual mencapai kurang lebih satu hingga tiga persen dari keseluruhan jumlah penduduknya (Hendriani, Handariyati, \& Sakti, 2006). Anak dengan disabilitas intelektual pada umumnya sangat bergantung pada pengasuh atau orang dewasa terdekatnya dalam melaksanakan kegiatan sehari-hari. Besarnya bantuan yang dibutuhkan oleh anak perlu disesuaikan dengan tingkat keparahannya, yang ditentukan berdasarkan fungsi adaptif dari anak. Penelitian kali ini lebih menekankan pada fungsi adaptif dalam ranah praktikal atau biasa disebut kemampuan bina diri (personal care).

Beberapa kemampuan yang termasuk ke dalam kemampuan bina diri diantaranya adalah buang air pada tempatnya, mengenakan pakaian, makan, mandi, serta membersihkan diri secara mandiri (Mehta, Pande, \& Bhargava, 1991). Penguasaan keterampilan bina diri merupakan tahapan pertama dari proses pencapaian kemandirian seseorang dan keterampilan tersebut akan terus digunakan sepanjang usia anak (Ardic \& Cavkaytar, 2014).

Anak dengan disabilitas intelektual memiliki defisit pada kemampuan bina diri. Adapun beberapa kemampuan yang termasuk kemampuan bina diri antara lain keterampilan makan dan membersihkan diri (toileting activities) seperti menyikat gigi, mandi, serta mengenakan pakaian secara mandiri (Marotz \& Allen, 2013). Banyak anak dengan disabilitas intelektual yang masih kesulitan melakukan tugas-tugas tersebut, bahkan hingga mereka menginjak usia remaja. Akibatnya, tidak sedikit orangtua selaku pengasuh utama, yang harus selalu mendampingi dan membantu anak melakukan kegiatan bina diri tersebut.

Salah satu jenis intervensi yang banyak digunakan untuk meningkatkan kemampuan bina diri pada anak dengan disabilitas intelektual ialah modifikasi perilaku (Miltenerger, 2012; Iscan, Nurcin, \& Fazlioglu, 2016). Terdapat beberapa cara yang dapat dilakukan untuk melatih kemampuan bina diri pada anak berkebutuhan khusus, salah satunya dengan modifikasi perilaku. Modifikasi perilaku merupakan jenis intervensi yang menggunakan proses analisis fungsi perilaku serta prosedur yang bertujuan untuk mengubah (meningkatkan atau mengurangi) perilaku ataupun membentuk perilaku baru (Miltenberger, 2012).

Modifikasi perilaku banyak digunakan bagi anak-anak dengan kebutuhan khusus, seperti autisme, ADHD, intellectual disability, dan lain-lain untuk berbagai jenis masalah perilaku (Kaur \& Kumar, 2013; Iscan dkk, 2016). Program modifikasi perilaku pada penelitian ini berfokus dalam meningkatkan self-dressing skill atau keterampilan mengenakan pakaian secara mandiri. Teknik modifikasi perilaku yang banyak digunakan untuk meningkatkan keterampilan berpakaian pada anak dengan moderate ID yang telah diteliti di penelitian-penelitian sebelumnya ialah chaining, baik forward chaining maupun backward chaining (Nida \& Tjakrawiralaksana, 2017; Juandi \& Tirta, 2018; Silmina \& Djuwita, 2018). Meski demikian, belum banyak penelitian yang menggunakan teknik prompting dalam meningkatkan keterampilan berpakaian. Padahal, teknik prompting dirasa lebih sederhana dan lebih mudah untuk dilakukan pengasuh anak. Untuk itu, 
penelitian kali ini ingin meneliti efektivitas modifikasi perilaku dengan teknik most-toleast prompting yang disertai pemberian positive reinforcement dengan token economy.

Berdasarkan pemaparan Kazdin (2013), positive reinforcement merupakan pemberian hal positif untuk meningkatkan probabilitas munculnya perilaku yang diharapkan di masa mendatang. Pemberian reinforcement akan menggunakan prosedur token economy. Berdasarkan pembahasan Matson dan Boisjoli (2009), token economy dapat diaplikasikan pada anak dengan ID dan terbukti efektif untuk berbagai target perilaku seperti meningkatkan kemampuan bina diri, mengerjakan tugas tepat waktu (task completion), dan lain-lain. Token economy pada umumnya diimplementasikan dengan cara memberikan sebuah token dalam periode waktu tertentu setiap kali anak menunjukkan perilaku yang diinginkan. Setelah itu, anak dapat menukarkan token dengan reward di akhir periode berupa item atau kegiatan yang lebih bernilai bagi anak.

Selanjutnya, teknik lain yang umum digunakan dalam program modifikasi perilaku adalah teknik prompting. Prompting ialah pemberian panduan atau bantuan dalam derajat tertentu untuk mencapai sebuah tujuan (Miltenberger, 2012). Teknik prompting sendiri dapat diaplikasikan melalui berbagai prosedur, salah satunya ialah most-to-least prompting, dimana kualitas prompt akan diberikan mulai dari yang paling konkret hingga kurang konkret (Iscan dkk, 2016). Terdapat empat jenis prompt yang dapat diaplikasikan dalam program modifikasi perilaku, yakni prompt fisik, modeling (demonstrasi), gestur, serta verbal (Miltenberger, 2012).

Prompt fisik merupakan bantuan yang diberikan secara fisik agar anak dapat memunculkan perilaku yang tepat. Sementara itu, modeling prompt ialah bantuan berupa demonstrasi dimana anak dapat mengamati dan meniru perilaku tersebut secara bersamaan. Selanjutnya, prompt gestur merupakan bantuan berupa gerakan fisik atau gestur di hadapan anak, dan prompt verbal hanya berupa instruksi lisan untuk membantu anak memunculkan perilaku yang tepat.

Prosedur most-to-least prompting terbukti efektif dalam meningkatkan kemampuan berpakaian pada anak dengan autisme (Iscan dkk, 2016). Sementara itu, penelitian kali ini ingin mengetahui apakah prosedur most-to-least prompting juga efektif diaplikasikan pada remaja dengan moderate ID. Prosedur tersebut dirasa sesuai untuk remaja dengan moderate ID, yaitu partisipan penelitian ini, karena ia masih membutuhkan contoh atau bimbingan dalam melakukan kegiatan bina diri, seperti mengenakan pakaian serta membersihkan diri setelah buang air.

Program modifikasi perilaku pada penelitian ini bertujuan untuk meningkatkan keterampilan mengenakan pakaian secara mandiri. Anak dengan disabilitas intelektual sangat rentan terhadap pelecehan seksual serta tindakan tidak bertanggungjawab lainnya dari orang lain (Hendriani dkk, 2006). Untuk itu, anak perlu mampu berpakaian secara mandiri untuk melindungi bagian privatnya dari orang lain selain pengasuh. Dimensi atau satuan perilaku yang akan diukur dan dikurangi pada program ini adalah durasi yang dibutuhkan partisipan untuk selesai memakai pakaian dengan benar. Adapun yang termasuk dalam perilaku mengenakan pakaian ialah perilaku memakai baju (kaus dan kemeja kancing) serta memakai celana dan rok. Dengan semakin berkurangnya durasi yang dibutuhkan anak untuk mengenakan pakaian, anak dinyatakan semakin terampil dalam berpakaian dan diharapkan dapat menunjukkan perilaku tersebut di berbagai konteks sehingga tidak lagi bergantung pada ibu.

\section{METODE PENELITIAN Desain Penelitian}

Penelitian ini menggunakan single subject design $(\mathrm{N}=1)$ dengan one group pretest-posttest yang bertujuan untuk 
melihat perbandingan dengan cara mengukur skor partisipan sebelum dan setelah diberikan program intervensi.

\section{Partisipan}

Partisipan dalam program ini adalah D, yaitu anak berusia 14 tahun 11 bulan dengan keterbatasan intelektual. Saat ini D menempuh pendidikan di kelas 1 SMP di sekolah inklusi. Berdasarkan hasil pemeriksaan psikologis, D memiliki skor IQ sebesar 44 pada skala Stanford-Binet (Form L-M). Ia memiliki usia mental 5 tahun 4 bulan. Hasil tersebut menunjukkan bahwa taraf kecerdasan D berfungsi pada taraf intellectual disability golongan moderate.

D memiliki keterbatasan pada domain konseptual, praktikal, serta sosial. Pada domain konseptual, D memiliki penguasaan konsep dasar dan akademis yang terbatas, serta lambat dalam mempelajari berbagai konsep. Pada domain praktikal, D memiliki ketergantungan yang cukup tinggi terhadap orang dewasa untuk melakukan kegiatan sehari-hari. Kemudian pada domain sosial, D memiliki hambatan dalam menjalin relasi dengan teman sebaya serta memiliki pemahaman konteks sosial yang terbatas.

Berdasarkan hasil pemeriksaan psikologis, terlihat bahwa kemampuan bina diri $\mathrm{D}$ tergolong rendah dibandingkan dengan anak seusianya. Hasil AAMD Adaptive Behavior Scale menunjukkan bahwa kemampuan bina diri D setara dengan rata-rata anak yang memiliki moderate intellectual disability. Meski demikian, ia tidak memiliki masalah motorik kasar maupun motorik halus. Selain itu, D juga tidak menunjukkan adanya tingkah laku maladaptif yang signifikan. Hanya saja, ia menunjukkan kecenderungan menarik diri dari lingkup sosialnya dan terlihat pasif di berbagai situasi.

Di usianya yang sudah menginjak tahapan remaja ini, kemampuan merawat diri yang dasar belum juga dikuasai dengan baik.

Contohnya, berpakaian, membersihkan diri setelah buang air $\mathrm{kecil} /$ besar, mengganti pembalut, dan lainlain. Dengan terbatasnya kemampuan tersebut, D masih sangat membutuhkan banyak bantuan dari keluarga maupun guru di sekolah.

\section{Variabel Penelitian}

Terdapat dua variabel dalam penelitian ini, yaitu intervensi modifikasi perilaku serta keterampilan berpakaian anak. Intervensi modifikasi perilaku bertindak sebagai variabel independen, sementara keterampilan berpakaian ialah variabel bebas.

\section{Instrumen Penelitian}

Instrumen yang digunakan pada penelitian kali ini ialah wawancara, lembar observasi, serta kuesioner self-care assessment (oleh Baker dkk, 2009). Pertama, self-care assessment berisi itemitem yang mengukur penguasaan kemampuan berpakaian serta motivasi anak dalam mengenakan pakaian. Salah satu contoh item dalam self-care assessment antara lain "Mengenakan kemeja berkancing depan", dimana ibu dapat mengisi satu (langkah dasar belum dikuasai), dua (membutuhkan bantuan), atau tiga (mampu secara mandiri).

Selanjutnya, instrumen lain yang digunakan adalah lembar observasi yang dikembangkan oleh peneliti. Lembar observasi yang digunakan mencakup jenis pakaian, kolom penulisan durasi, jumlah stiker yang didapatkan, serta kolom keterangan. Adapun indikator perilaku mengenakan pakaian pada program ini mencakup lima jenis pakaian, yaitu: bra, kaus lengan pendek, celana berkancing dengan ritsleting, kemeja lengan panjang serta rok (seragam sekolah). Jenis-jenis pakaian tersebut merupakan pakaian dasar yang kerap digunakan D sehari-hari di rumah maupun di sekolah.

Durasi mengenakan pakaian mulai dihitung sejak peneliti selesai memberikan instruksi, hingga D selesai mengenakan pakaian dengan tepat dan lengkap. 
Pengukuran durasi tidak akan dihentikan apabila D masih melakukan kesalahan dalam mengenakan pakaian, seperti: baju/celana dalam posisi terbalik, kancing atau ritsleting tidak terkait, atau ada kancing yang belum terpasang. Durasi tersebut dihitung menggunakan timer.

\section{Prosedur Penelitian}

Penelitian ini dimulai dengan pemilihan partisipan dengan teknik purposive sampling, yakni memilih partisipan berdasarkan karakteristik yang telah ditetapkan, yaitu remaja dengan moderate intellectual disability. Setelah itu, dilakukan tahap pra-intervensi.

Tahap pra-intervensi terdiri dari tiga sesi, yang mencakup asesmen kebutuhan, asesmen reinforcer, pengambilan data baseline, serta analisis fungsi perilaku. Asesmen kebutuhan dilakukan dengan mewawancara ibu dan observasi anak, mengenai dimensi target perilaku yang akan diintervensi. Selanjutnya, peneliti juga mengadministrasikan self-care assessment (oleh Baker dkk, 2009), yaitu ceklis yang terdiri dari beberapa kemampuan bina diri. Dalam studi kali ini, peneliti hanya menggunakan beberapa item yang berkaitan dengan kemampuan berpakaian secara mandiri. Ceklis ini diisi oleh peneliti berdasarkan wawancara kepada ibu dari anak.

Selanjutnya, untuk mengidentifikasi positive reinforcer yang efektif bagi anak, perancang program melakukan wawancara sebagai asesmen reinforcer. Pedoman wawancara yang digunakan adalah kuesioner untuk mengidentifikasi reinforcer yang efektif pada buku Martin dan Pear (2015). Adapun jenis-jenis reinforcer yang diidentifikasi dalam program modifikasi perilaku antara lain consumable reinforcer (makanan dan minuman), kegiatan (waktu bermain dengan orangtua, bertamasya ke tempat tertentu), serta barang (mainan, buku, dan lain-lain).

Setelah itu, peneliti juga melakukan functional behavioral analysis (FBA), yakni sebuah proses dalam modifikasi perilaku untuk mengidentifikasi target perilaku, tujuan dari perilaku, serta faktor apa yang mempertahankan kemunculan perilaku tersebut (Martin \& Pear, 2015). Hasil dari proses FBA akan menentukan prosedur dari program modifikasi perilaku. Adapun hasil FBA terhadap perilaku D tertera pada tabel 1 .

Terakhir, peneliti mengambil data baseline sebanyak tiga sesi (satu sesi per hari). Pada tahap baseline, anak diminta untuk mengenakan pakaian secara mandiri, tanpa bantuan apapun dari orang lain. Anak diberikan dua kali kesempatan untuk mengenakan setiap jenis pakaian, sehingga terdapat jumlah 10 trial dalam satu sesi.

Tahap selanjutnya ialah tahap intervensi, yang terbagi ke dalam tiga fase. Setiap fase memiliki tingkat kesulitan yang berbeda berdasarkan kualitas prompt serta target pencapaian yang berbeda (lihat Tabel 2). Tahap intervensi ini berjumlah 15 sesi (satu sesi per hari, dilaksanakan selama tiga minggu). Setiap sesi berlangsung selama 40 - 70 menit, bergantung pada durasi yang dibutuhkan anak untuk selesai mengenakan pakaian secara tepat. 
Tabel 1

Functional Behavioral Analysis

\begin{tabular}{ccc}
\hline & Problem Behavior & \\
\hline Antecedent & Behavior & Consequence \\
\hline Kesulitan dalam & Selalu meminta bantuan & Ibu selalu membantu mengenakan \\
mengenakan pakaian secara & ibu dalam mengenakan \\
mandiri. & pakaian; Menolak untuk & \\
& mengenakan pakaian & \\
& secara mandiri; & \\
& Mengenakan pakaian \\
& dalam waktu yang lama. \\
\hline
\end{tabular}

Pelaksana intervensi dalam program ini adalah peneliti serta ibu dari D, selaku pengasuh utama, secara berselang-seling (Peneliti: Senin, Rabu, dan Jumat; Ibu: Selasa dan Kamis) dalam satu minggu. Peneliti sudah memberikan pelatihan kepada ibu mengenai penggunaan teknik prompting serta pemberian reinforcement saat tahap pra-intervensi Hal tersebut dilakukan sebagai proses generalisasi pada peningkatan keterampilan berpakaian D. Di sesi terakhir, peneliti kembali memberikan self-care assessment yang diisi oleh ibu.

Tahap terakhir ialah tahap followup, yang dilakukan empat minggu setelah program intervensi selesai diberikan. Sesi follow-up dilakukan sebanyak tiga sesi (satu sesi per hari). Selain itu, self-care assessment kembali diberikan kepada ibu. Sesi follow-up ditujukan untuk melihat apakah peningkatan keterampilan anak dalam mengenakan pakaian dapat bertahan dalam jangka waktu yang panjang setelah program selesai dilaksanakan.

\section{Program Intervensi}

Program modifikasi perilaku kali ini menggunakan pemberian reinforcement dengan sistem token economy serta pemberian teknik prompting. Anak akan mendapatkan positive reinforcement berupa token (stiker) setiap kali ia mencapai target harian. Di akhir pekan, anak dapat menukarkan stiker dengan back-up reinforcer kepada ibu. Program modifikasi perilaku ini terbagi ke dalam tiga fase, dimana setiap fase berjalan selama satu minggu. Dalam setiap fase, anak akan mendapatkan kualitas prompt yang semakin menurun intensitasnya, serta target durasi yang semakin cepat sehingga tingkat kesulitannya semakin meningkat (lihat tabel 2). 
Tabel 2

Tahapan Program Intervensi

\begin{tabular}{|c|c|c|c|c|c|}
\hline \multirow{3}{*}{ Jenis Pakaian } & \multicolumn{5}{|c|}{ Tahap } \\
\hline & $\begin{array}{l}\text { Baseline } \\
(3 \text { sesi) }\end{array}$ & $\begin{array}{c}\text { Fase } 1 \\
(\text { sesi } 1-5)\end{array}$ & $\begin{array}{c}\text { Fase } 2 \\
(\text { sesi } 6-10)\end{array}$ & $\begin{array}{c}\text { Fase } 3 \\
(\text { sesi } 11-15)\end{array}$ & $\begin{array}{c}\text { Follow-up } \\
\text { (3 sesi) }\end{array}$ \\
\hline & \multicolumn{5}{|c|}{ Target Durasi Perilaku Mengenakan Pakaian } \\
\hline Bra & - & 7 menit & 5 menit & 2 menit & - \\
\hline Kaus & - & 5 menit & 3 menit & 1 menit & - \\
\hline $\begin{array}{l}\text { Kemeja } \\
\text { berlengan }\end{array}$ & - & 7 menit & 5 menit & 2 menit & - \\
\hline $\begin{array}{l}\text { Celana } \\
\text { berkancing }\end{array}$ & - & 5 menit & 3 menit & 1 menit & - \\
\hline Rok & - & 7 menit & 5 menit & 2 menit & - \\
\hline $\begin{array}{l}\text { Jenis } \\
\text { Pemberian } \\
\text { Prompt } \\
\end{array}$ & $\begin{array}{c}\text { No } \\
\text { prompt }\end{array}$ & $\begin{array}{l}\text { Physical (2 sesi) } \\
\text { dan Modeling (3 } \\
\text { sesi) }\end{array}$ & Gestural & $\begin{array}{l}\text { Verbal (3 sesi) dan } \\
\text { No Prompt ( } 2 \text { sesi) }\end{array}$ & No prompt \\
\hline Reinforcement & $\begin{array}{c}\text { No } \\
\text { reinforcer }\end{array}$ & $\begin{array}{c}\text { - } 15 \text { - } 20 \text { stiker: } \\
\text { makanan } \\
\text { - } 20 \text { - } 25 \text { stiker: } \\
\text { barang } \\
\text { - } 25 \text { stiker: } \\
\text { aktivitas }\end{array}$ & $\begin{array}{c}\text { - } 25 \text { - } 30 \text { stiker: } \\
\text { barang } \\
\text { - } 31 \text { - } 35 \text { stiker: } \\
\text { aktivitas } \\
\text { - } 35 \text { stiker: } \\
\text { aktivitas }\end{array}$ & $\begin{array}{c}\text { - } 35-40 \text { stiker: } \\
\text { barang } \\
\text { - } 41-45 \text { stiker: } \\
\text { barang } \\
\text { - } 46-50 \text { stiker: } \\
\text { aktivitas }\end{array}$ & $\begin{array}{c}\text { No } \\
\text { reinforcer }\end{array}$ \\
\hline
\end{tabular}

Pada fase pertama (sesi $1-5)$, anak mendapatkan dua jenis prompt, yaitu prompt fisik pada sesi pertama dan kedua, lalu berkurang menjadi modeling prompt di sesi ketiga hingga kelima. Contoh pemberian prompt fisik pada anak ialah dengan menyentuh tangan anak dan mengarahkannya ke arah lubang kancing yang tepat. Sementara itu, contoh modeling prompt ialah dengan berada di hadapan anak, dan mengenakan pakaian sebagai demonstrasi.

Selanjutnya pada fase dua (sesi enam - 10), intensitas prompt kembali berkurang menjadi prompt gestur. Pada fase ini, peneliti ataupun ibu dapat memberikan bantuan dengan cara menunjuk ke arah yang harus diperhatikan oleh anak saat mengenakan pakaian. Pada fase ini, target durasi yang harus dicapai oleh anak juga semakin menurun, artinya anak dituntut untuk mengenakan pakaian secara tepat dalam waktu yang lebih cepat.

Setelah itu, di fase tiga peneliti hanya menggunakan prompt verbal (berupa instruksi lisan) di sesi ke-11 hingga ke-13, lalu tidak menggunakan prompt sama sekali di sesi ke-14 dan 15. Semakin berkurangnya kualitas prompt merupakan penerapan sistem fading atau transfer of stimulus control, yakni anak diharapkan dapat memunculkan perilaku yang diharapkan dengan bantuan seminimal mungkin seiring berjalannya program.

Dalam satu sesi intervensi, terdapat 10 kali trial, yang terdiri dari dua trial untuk lima jenis pakaian (bra, kaus berlengan, kemeja berlengan, celana, dan rok). Setiap memulai trial, peneliti menginstruksikan anak untuk mengenakan pakaian dalam waktu yang secepatcepatnya hingga terpasang dengan benar. Peneliti menyalakan timer pada saat anak mulai mengenakan pakaian, dan menghentikan timer saat anak selesai mengenakan pakaian dengan benar. Keberhasilan program ditandai dengan tercapainya target durasi mengenakan pakaian pada fase tiga (lihat tabel 2), tanpa bantuan/prompt. 


\section{Teknik Analisis Data}

Teknik analisis data dalam penelitian ini menggunakan teknik statistik deskriptif dengan penggunaan grafik. Analisis data untuk melihat keberhasilan program dilakukan dengan cara

ANALISIS DAN HASIL

Hasil pengukuran keterampilan berpakaian saat baseline tergolong rendah, yakni ia membutuhkan waktu yang relatif lama untuk berpakaian dengan benar dibandingkan anak-anak seusianya. D juga banyak melakukan kesalahan seperti terbalik dalam memakai kaus atau memasukkan kancing pada lubang yang tidak sesuai, sehingga ia harus terus mengulang hingga membutuhkan waktu yang lama. Pada pengukuran baseline, D dapat mencapai waktu 15 menit untuk mengenakan bra, 8,5 menit untuk kaus berlengan, 20 menit untuk kemeja berkancing, 30 menit untuk celana dengan ritsleting, serta 8,5 menit untuk mengenakan rok. Secara keseluruhan, D membutuhkan waktu kurang lebih 70 hingga 80 menit untuk berhasil mengenakan kelima jenis pakaian dengan benar.

Hasil self-care assessment juga sejalan dengan hasil observasi, dimana ibu menilai bahwa penguasaan keterampilan serta motivasi D dalam berpakaian secara mandiri tergolong rendah dan bermasalah. Terdapat beberapa kemampuan yang dinilai belum dikuasai oleh $\mathrm{D}$ seperti mengenakan bra, kemeja berkancing, celana atau rok membandingkan durasi mengenakan pakaian secara mandiri, sebelum (data baseline) dan setelah (data posttest dan follow-up) intervensi diberikan pada anak.

dengan ritsleting, serta mengikat tali sepatu. Sementara itu, beberapa kemampuan yang sudah dikuasai langkah dasarnya, namun masih memerlukan bantuan, ialah mengenakan celana dan kaus dalam, celana karet, kaus, serta ikat pinggang.

Setelah pengambilan data baseline, D mendapatkan sesi intervensi sejumlah 15 sesi yang diberikan oleh peneliti dan ibu dari D. Peneliti memberikan intervensi di sesi kesatu, ketiga, kelima, keenam, kedelapan, 10, 11, 13, dan 15, sementara ibu D di sesi kedua, keempat, ketujuh, kesembilan, 12, dan 14. Seluruh pelaksanaan sesi berjalan cukup lancar. D dapat menjalankan instruksi dari peneliti maupun ibu. Orangtua, terutama ibu D cukup kooperatif dan konsisten dalam memberikan instruksi, prompt, maupun reinforcement sesuai panduan yang telah dirancang dan dilatihkan oleh peneliti. Berikut ini merupakan perbandingan durasi mengenakan pakaian (dalam menit) pada kelima jenis pakaian, mulai dari tahap baseline, tahap intervensi (15 sesi) dan tahap follow up. Durasi yang tertera pada grafik merupakan waktu yang direkam mulai dari peneliti selesai memberikan instruksi, hingga anak selesai mengenakan satu jenis pakaian. 


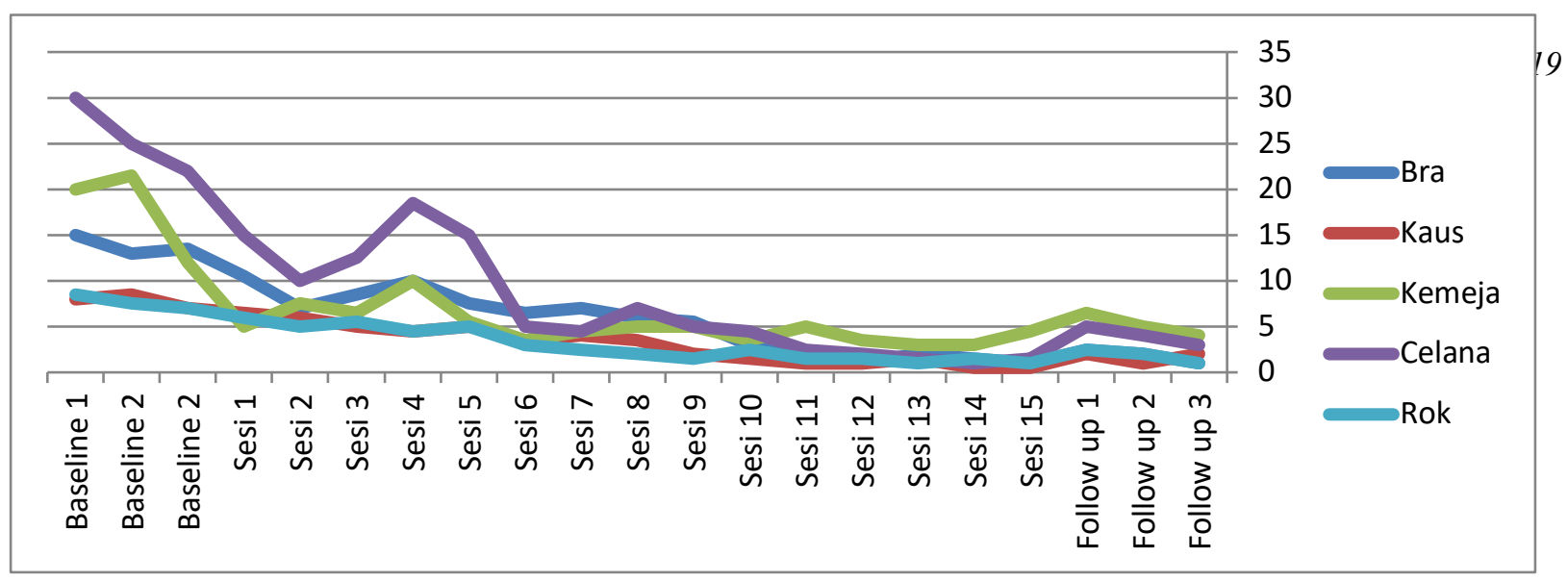

Gambar 1. Perbandingan durasi mengenakan pakaian (dalam menit).

Berdasarkan grafik (gambar 1), terlihat adanya penurunan yang signifikan pada durasi berpakaian saat baseline, posttest serta follow-up. Secara keseluruhan, anak dapat mengenakan pada posttest menurun drastis hingga enam sampai tujuh menit. Meski demikian, total durasi mengenakan pakaian pada saat follow-up lebih lama dibandingkan dengan posttest, tetapi jauh lebih cepat bila dibandingkan dengan tahap baseline, yakni mencapai 14 - 17 menit untuk kelima jenis pakaian.

Selama program intervensi berjalan, terlihat penurunan durasi mengenakan pakaian yang signifikan antara baseline dan dua sesi pertama, khususnya pada jenis pakaian bra, kemeja serta celana berkancing. Berdasarkan hasil wawancara dengan ibu maupun anak, ketiga jenis pakaian tersebut merupakan yang paling sulit untuk dikenakan secara mandiri. Total durasi yang dibutuhkan untuk ketiga jenis pakaian tersebut menurun dari 65 menit (baseline satu) menjadi 15,5 menit (sesi dua). Peningkatan keterampilan tersebut terjadi ketika anak diberikan bantuan berupa prompt fisik. Anak berhasil lebih cepat mengenakan pakaian ketika diberikan bantuan seperti mengarahkan langsung tangan anak pada kancing baju atau celana.

Selanjutnya, terapat peningkatan durasi pada sesi ketiga dan keempat, dimana prompt yang diberikan beralih menjadi modeling prompt, tidak lagi secara fisik. Hal tersebut menandakan bahwa dengan berubahnya kualitas bantuan (dari jenis yang lebih intrusif ke jenis yang kurang intrusif), anak menghadapi tingkat pakaian secara mandiri dengan lebih cepat. Pada tahap baseline, anak membutuhkan total waktu $70-80$ menit untuk mengenakan kelima jenis pakaian, sementara

kesulitan yang lebih tinggi dan perlu waktu penyesuaian serta usaha yang lebih besar. Meski demikian, dengan adanya treatment yang konsisten, anak dapat berlatih meningkatkan keterampilan berpakaiannya, terlihat dari kembali menurunnya durasi pada sesi kelima dan keenam.

Terlihat bahwa grafik penurunan durasi sepanjang program intervensi cukup stabil, hingga anak berhasil mencapai total durasi 8,5 menit pada sesi intervensi terakhir tanpa bantuan. Setelah itu, hasil follow-up yang diambil empat minggu setelah sesi terakhir juga menunjukkan bertahannya efek dari program modifikasi perilaku pada anak, yakni anak berhasil mencapai total durasi 11 menit untuk mengenakan kelima jenis pakaian. Meskipun anak membutuhkan total waktu yang sedikit lebih lama di sesi follow-up, peningkatan keterampilan berpakaian tergolong signifikan, yakni hampir enam kali lipat lebih cepat dibandingkan dengan sebelum anak mendapatkan intervensi.

Meningkatnya keterampilan berpakaian pada anak juga terlihat dari hasil self-care assessment yang diisi oleh ibu. Ibu menyatakan bahwa keterampilan berpakaian anak sangat meningkat, dan juga bertahan hingga tahap follow-up (lihat gambar 2). Saat ini, anak tidak lagi memerlukan bantuan untuk berpakaian, hanya saja sesekali membutuhkan 


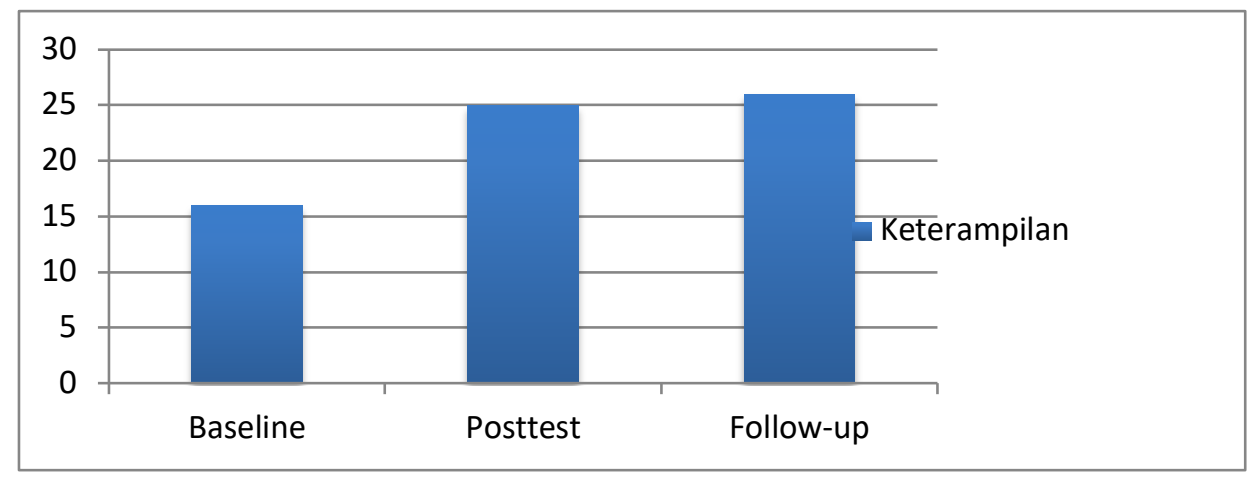

Gambar 2. Perbandingan hasil self-care assessment.

Selanjutnya, hasil penelitian ini juga menunjukkan bahwa selain meningkatnya keterampilan berpakaian, anak juga mengalami peningkatan motivasi dalam mengenakan pakaian secara mandiri. Hal tersebut terlihat dari hasil self-care assessment, yang berdasarkan observasi serta wawancara ibu. Secara keseluruhan, anak dinilai lebih mampu menguasai keterampilan berpakaian, serta memiliki motivasi yang lebih tinggi untuk berpakaian secara mandiri setelah mendapatkan intervensi.

Selama program intervensi berjalan, ibu melaporkan bahwa anak beberapa kali meminta berlatih mengenakan pakaian dengan ibu di akhir pekan, agar dapat berpakaian dengan lebih cepat ketika akan menjalani sesi dengan peneliti keesokan harinya. Selain itu, anak juga menjadi lebih sering berinisiatif untuk mengenakan pakaian secara mandiri, seperti sebelum dan sepulang sekolah. Sejak sesi ke-13, anak juga selalu terlihat merapikan pakaiannya setelah terpasang dengan benar. Contohnya, ketika selesai mengenakan rok setelah kemeja (seragam sekolah), anak selalu terlihat merapikan sisi bawah kemeja agar lebih rapi dan nyaman. Ia juga tidak lagi khawatir pergi ke sekolah ketika ada jam pelajaran olahraga, karena ia sudah mampu mengganti pakaiannya sendiri. Selain itu, anak juga mulai mau membiasakan diri menaruh baju kotor pada tempatnya.

Setelah periode intervensi selesai, terlihat bahwa keterampilan berpakaian bertahan hingga sesi follow-up, menandakan bahwa peningkatan keterampilan berpakaian bertahan pada anak meskipun intervensi tidak lagi diberikan. Meski demikian, terlihat adanya sedikit penurunan pada motivasi di fase follow-up. Dengan penerapan disiplin atau rutinitas berpakaian yang konsisten, anak diprediksi mampu mempertahankan tidak hanya keterampilan, namun juga motivasi berpakaian secara mandiri.

\section{DISKUSI}

Sejalan dengan penelitian sebelumnya, penelitian kali ini membuktikan bahwa program modifikasi perilaku, khususnya dengan teknik token economy serta most-to-least prompting, efektif dalam meningkatkan kemampuan bina diri pada anak dengan keterbatasan intelektual (Matson \& Boisjoli, 2009; Iscan dkk, 2016). Di tahap pertama, penurunan durasi berpakaian yang signifikan terjadi ketika anak diberikan prompt fisik. Hal tersebut juga sejalan dengan studi sebelumnya yang menyatakan bahwa anak dengan disabilitas intelektual membutuhkan contoh konkret serta metode bantuan yang cukup intrusif di awal masa 
pembelajaran (Matson, Mahan, \& LoVullo, 2009).

Selain itu, penelitian ini juga menemukan pola yang konsisten, dimana anak cenderung mengalami sedikit penurunan ketika pergantian jenis prompt, namun akan kembali meningkat setelah satu hingga dua sesi. Untuk itu, orangtua perlu mengantisipasi pola tersebut dalam pengajaran kemampuan bina diri dan tidak perlu khawatir apabila kemampuan anak tidak akan berkembang. Hal tersebut mengindikasikan bahwa anak membutuhkan waktu penyesuaian, dan pengasuh perlu secara konsisten melatih agar keterampilan terus meningkat.

Terdapat beberapa faktor yang mempengaruhi hasilan penelitian ini, antara lain:

1. Kontribusi orangtua, terutama ibu sebagai pengasuh utama, sangat membantu peningkatan keterampilan berpakaian pada anak. Ibu bersikap kooperatif, memiliki keinginan belajar yang tinggi, serta selalu mempraktekkan kemampuan melatih yang telah diajarkan oleh peneliti. Meskipun sesekali ibu kurang konsisten (contoh, cenderung memberikan bantuan fisik ketika anak sudah memasuki tahap prompt gestur karena telah terbiasa membantu), namun pada akhirnya kebiasaan tersebut semakin berkurang.

2. Jenis reinforcer yang tepat sangat membantu dalam meningkatkan motivasi anak, baik dari token maupun back-up reinforcer. Daftar back-up reinforcer yang tertulis di buku stiker juga membantu meningkatkan motivasi anak, sehingga anak mengetahui target yang harus dicapai apabila ia menginginkan reward tertentu.

3. Suasana hati anak selama proses intervensi sangat penting untuk diperhatikan. Anak dapat merasa frustrasi apabila ia tidak berhasil berpakaian dengan benar dalam waktu yang lama. Ketika anak sudah terlihat kesal dan ingin menyerah, pemberi intervensi perlu memberikan waktu istirahat, dan tentunya pujian (social reinforcement) bagi anak karena telah berusaha. Dengan begitu, anak tidak merasa terbeban dan justru termotivasi untuk terus mencoba.

\section{SIMPULAN}

Berdasarkan pemaparan di atas, dapat disimpulkan bahwa program modifikasi perilaku dengan teknik prompting dan token economy terbukti efektif dalam meningkatkan keterampilan berpakaian pada anak dengan moderate intellectual disability. Hasil penelitian ini menunjukkan bahwa terdapat penurunan durasi berpakaian yang signifikan, yakni hampir enam kali lebih cepat yaitu dari total 65 menit (tahap baseline) hingga total 11 menit (tahap follow-up) untuk lima jenis pakaian. Hal tersebut menandakan bahwa anak lebih terampil dalam mengenakan pakaian tanpa bantuan dari orangtua. Peningkatan keterampilan tersebut juga bertahan meskipun intervensi tidak lagi diberikan, terlihat dari hasil follow-up yang cukup stabil.

\section{SARAN}

Meski demikian, penelitian ini memiliki beberapa keterbatasan, salah satunya ialah jumlah partisipan yang tidak banyak. Untuk mengembangkan hasil penelitian ini, penelitian selanjutnya disarankan menggunakan partisipan lebih dari satu agar program modifikasi perilaku yang dirancang dapat digeneralisasikan secara lebih luas. Selain itu, penting juga untuk memberikan psikoedukasi yang terstruktur untuk orangtua setelah sesi follow-up, agar orangtua dapat mengerti pentingnya keberlanjutan penerapan program meskipun intervensi telah selesai diberikan. Hal tersebut penting dilakukan untuk mempertahankan konsistensi peningkatan keterampilan bina diri pada anak.

\section{DAFTAR PUSTAKA}

American Psychiatric Association (2013). Diagnostic and statistical manual of 
mental disorder

$\left(5^{\text {th }}\right.$

ed.). Washington DC: Author.

Ardic, A. \& Cavkaytar, A. (2014). Effectiveness of the modified intensive toilet training method on teaching toilet skills to children with autism. Education and Training in Autism and Developmental Disabilities, 49(2), 263-276.

Baker, B. L., Brightman, A. J., Blacher, J. B., Hinshaw, S. P., Heifetz, L. J., \& Murphy, D. M. (2009). Steps to independence: Teaching everyday skills to children with special needs ( $4^{\text {th }}$ ed.). Baltimore: Paul H Brookes Publishing Co.

Hendriani, W., Handariyati, R., \& Sakti, T. M. (2006). Penerimaan keluarga terhadap individu yang mengalami keterbelakangan mental. INSAN, $8(2), 100-111$.

Iscan, G. C., Nurcin, E., \& Fazlioglu, Y. (2016). Effect of most-to-least prompting procedure on dressing skill of students with autism. Educational Research and Reviews, 11(18), 1766 - 1774.

Juandi, N., \& Tirta, S. (2018). Penerapan forward chaining untuk meningkatkan kemampuan memakai baju pada anak penyandang disabilitas intelektual sedang. Jurnal Muara Ilmu Sosial, Humaniora, dan Seni, 2(1), 302 309.

Kaur, G., \& Kumar, M. (2013). Effect of stimulus shaping \& prompting in developing dressing skills in trainable mentally challenged among age group of $6-12$ years. International Journal of Science and Research, 4(6), 1195 - 1198.

Kazdin, A. E. (2013). Behavior Modification in applied settings $\left(7^{\text {th }}\right.$ ed.). Illinois: Waveland Press, Inc.

Mash, E. J., \& Wolfe, D. A. (2010). Abnormal child psychology. $\left(4^{\text {th }}\right.$ ed.). California: Wadsworth.
Marotz, L. Y., \& Allen, E. K. (2013). Developmental profiles: Pre-birth through adolescence ( $7^{\text {th }}$ ed.). California: Wadsworth.

Martin, G., \& Pear, J. (2015). Behavior modification: What it is and how to do it $\left(10^{\text {th }}\right.$ ed.). USA: Pearson Education, Inc.

Matson, J. L. \& Boisjoli, J. A. (2009). The token economy for children with intellectual disability and/or autism: A review. Research in Developmental Disabilities, 30, 240 $-248$.

Matson, J. L., Mahan, S., \& LoVullo, S. V. (2009). Parent training: A review of methods for children with developmental disabilities. Research in Developmental Disabilities, 30, 961 - 968.

Mehta, M., Pande, P., \& Bhargava, M. (1991). Behavioral training for mothers of mentally handicapped children: Teaching of self-help skills. Indian Pediatrics, 98, 909 915.

Miltenberger, R.G. (2012). Behavior modification principles and procedures $\left(5^{\text {th }}\right.$ ed.). USA: Cengage Learning.

Nida, D.A.D.T.P.P., \& Tjakrawiralaksana, M. A. (2017). Teaching selfdressing skill behavior in a child with moderate intellectual disability and low vision with backward chaining technique. Advances in Social Science, Education and Humanities Research, 135, 166 177.

Silmina, A.A., \& Djuwita, E. (2018). Penerapan modifikasi perilaku untuk meningkatkan kemampuan memakai kaos berlengan pada anak dengan disabilitas intelektual tingkat berat. Humanitas, 2(1), 1 14. 